\title{
ДОСВІД РОЗРОБКИ І ВПРОВАДЖЕННЯ ВІРТУАЛЬНИХ ПРОГРАМ 3 БІОХІМІЇ В НАВЧАЛЬНИЙ ПРОЦЕС
}

\author{
Г. Г. Шершун, М. М. Корда \\ ДВНЗ “Тернопільський державний медичний університет \\ імені І. Я. Горбачевського МОЗ Украйни”

\section{EXPERIENCE OF THE DEVELOPMENT AND IMPLEMENTATION OF VIRTUAL PROGRAMS ON BIOCHEMISTRY IN THE LEARNING PROCESS}

\author{
H. H. Shershun, M. M. Korda \\ SHEI "Ternopil State Medical University by I. Ya. Horbachevsky of MPH of Ukraine"
}

\begin{abstract}
У статті наведено досвід розробки декількох віртуальних навчальних програм з біохімії, їх використання в навчальному процесі студентів з метою поглибленого розуміння окремих метаболічних процесів та професійного спрямування майбутніх медиків і фармацевтів.

The article presents the experience of the development of several virtual training programs in biochemistry. The using of such programs in teaching process of students deepens the understanding of particular metabolic processes and allows to direct professionally the future physicians and pharmacists.
\end{abstract}

Вступ. Інтеграція у міжнародний науково-професійний простір вимагає нових інноваційних підходів до організації медичної освіти. При цьому набуває великого значення впровадження відкритої системи навчання, створення віртуального інформаційного ресурсу i використання віртуальних засобів навчання. Поняття “віртуальність" використовується давно і щодо різних галузей науки і суспільства. Але найбільшу популярність цей термін набув при комп'ютерному моделюванні певних ситуацій. В освітній діяльності студентів при використанні поняття “віртуальність" мова йде про впровадження мультимедійних, телекомунікаційних та інших електронних засобів і технологій навчання. Ефективність навчально-пізнавальної діяльності, рівень підготовки студентів-медиків значно підвищується за активного впровадження інноваційних інтерактивних технологій навчання, але досвід розробок, впровадження предметних віртуальних програм у навчальному процесі медичних вузів практично відсутній. Автори зробили спробу поділитись поки що невеликим досвідом розробки і використання в навчальному процесі студентів медичних ВНЗ віртуальних програм 3 біохімії.
Основна частина. У ТДМУ створено відділ віртуальних навчальних програм, завданням якого $\epsilon$ створення бази таких програм, розроблених кафедрами, їх тестування, апробація у навчальному процесі, вдосконалення. Власного досвіду розробок віртуальних програм з біохімії не було, пошук таких матеріалів практично не дав результатів через їх відсутність або недоступність, тому залишався варіант власного бачення проблеми. Отже, наші підходи до розробки програм передбачали такі етапи:

- складання тематичного плану програм, який включав найпоказовіші біохімічні шляхи, біохімічні системи, цикли, які доступні для комп'ютерного моделювання, мають максимальне професійне спрямування, поєднані з темами всіх практичних занять курсу біохімії;

- розробка сценарію кожної конкретної програми, що включає підбір необхідних формул, символів, схем, малюнків, термінів, картинок, складання питань і варіантів відповідей на них;

- структурування програми відповідно до вимог відділу віртуальних навчальних програм, що передбачають 4-5 частин:

• теоретичні відомості;

(ㄷ Г. Г. Шершун, М. М. Корда 
• узагальнення функцій об' єктів програми;

- хімічна будова об'єктів програми;

- діагностичне значення біохімічних показників, що використовуються у програмі, диференційна діагностика хвороб за біохімічними показниками тощо.

Вищенаведені пункти програми не передбачають оцінювання, а мають навчальну ціль;

- проходження студентом заданого процесу шляхом послідовного вибору правильних відповідей на питання. Дана частина передбачає фіксування помилкових відповідей, що є підставою для оцінки;

- зображення остаточного варіанта програми у вигляді цілісної системи, що дозволяє безпомилкове введення у комп'ютер усіх іï елементів у заданій послідовності. У відділ віртуальних програм подаються варіанти на паперовому та електронному носіях;

- тестування готової програми компетентною комісією, внесення доповнень, виправлень, необхідність яких диктується вимогами щодо ії використання в навчальному процесі.

Для прикладу наведемо структуру віртуальної програми “Біохімічний шлях гліколізу”. В частині “Теоретичні відомості” розкрито біологічну роль гліколізу, акцентовано увагу на тому, що цей процес започатковує метаболізм глюкози, $є$ першою ланкою взаємозв'язку обміну органічних сполук, підготовчою фазою спільних процесів деградації субстратів, забезпечує компенсацію енергії для життєдіяльності організму навіть за анаеробних умов, що нерідко супроводжують розвиток патологічних процесів.

У наступній частині програми представлена розроблена авторами схема метаболізму глюкози в

\section{Література}

1. Карпенко М. П. Телеобучение / М. П. Карпенко. М. : СГА, 2008. $-800 \mathrm{c}$.

2. Парфірова Т. С. Навчальні середовища як відкритозамкнені системи / Т. С. Парфірова // Вісн. Київ. ун-ту. Серія: “Фізико-математичні науки". -2009. -№ 1.-С. 127-132.

3. Коцюба Р. Б. Використання віртуальних навчальних програм при вивченні іноземної мови професійного спря- організмі. На схемі вказані всі перетворення, яких зазнає глюкоза. Схема наочно демонструє всебічні функції глюкози, легко запам'ятовується. Наступні етапи програми дозволяють згадати будову головних субстратів гліколізу, загальний вигляд анаеробного процесу. I накінець останній, п'ятий пункт, вимагає від студента пройти самостійно шлях анаеробного гліколізу способом вибору правильних відповідей (сполук, ферментів, коферментів) 3 декількох заданих. Пройшовши 20 кроків, студент отримує підсумковий результат, що вказує на кількість допущених помилок (чи їх відсутність).

За подібним принципом розроблено також віртуальні програми “Обмін жовчних пігментів у нормі”, “Роль нирок у регуляції кров' яного тиску”, підготовлено ряд інших. Студенти з великим інтересом ставляться до опрацювання наявних віртуальних програм, доцільність їх розробки і впровадження є очевидною.

Висновки: 1. Запропоновано принцип розробки віртуальних навчальних програм з біохімії.

2. Підтверджено доцільність розробки алгоритму програм у вигляді логічно пов'язаних між собою 4-5 пунктів, що містять і навчальні елементи, і тренінгові.

3. Досвід впровадження наявних програм у навчальний процес переконливо показав їх високу ефективність і відкриває нові можливості підвищення якості медичної освіти.

4. Вважаємо оптимальним кроком створення в перспективі банку віртуальних навчальних програм 3 біохімії, розрахованих для впровадження на всіх практичних заняттях.

мування / Р. Б. Коцюба // Інформаційні технології і засоби навчання. -2013. - Т. 37, № 5. - С. 43-52.

4. Ковальчук Л. Я. Впровадження новітніх методик і систем навчального процесу в Тернопільському державному медичному університеті ім. І. Я. Горбачевського / Л. Я. Ковальчук // Медична освіта. -2009. -№2. -C. 10-14.

Отримано 15.04.14 